\title{
An empirical analysis of contracting by Chinese firms
}

\author{
Yifan $\mathrm{HU}^{\mathrm{a}}$, Larry D. QIU ${ }^{\mathrm{b}, *}$ \\ a CITIC Securities, Hong Kong \\ b The University of Hong Kong, Hong Kong
}

\section{A R T I C L E I N F O}

\section{Article history:}

Received 18 December 2008

Received in revised form 14 March 2010

Accepted 22 March 2010

\section{JEL classification:}

D23

L14

Keywords:

Formal contracts

Relational contracts

Location

Chinese firms

\begin{abstract}
A B S T R A C T
Why do firms use formal contracts or relational contracts with their business partners? The paper uses survey data based on a large number of Chinese firms to uncover some important factors for why and when formal contracts or relational contracts are used. This study identifies geographical location as an important factor in affecting Chinese firms' contracting decisions. We find that a firm is more likely to use formal contracts with its clients and suppliers if they are located in a city different from the firm's main business location. We also find that larger (smaller) firms tend to adopt formal (relational) contracts. However, while the number of clients has a negative impact on a firm's adoption of formal contracts with its clients, the number of suppliers has a positive impact on its adoption of formal contracts with the suppliers.
\end{abstract}

(c) 2010 Elsevier Inc. All rights reserved.

\section{Introduction}

Businesses are often connected by contracts, explicitly or implicitly, formally or informally, in written or oral form. ${ }^{1}$ Some of the most important questions about contracts are why and when formal (explicit, written) contracts are signed, why and when informal (implicit, relational) contracts are used, and what the optimal contracts are. Using recently collected survey data on Chinese firms by the World Bank, we conduct an empirical study on when formal contracts are signed, which immediately indicates when relational contracts are adopted. ${ }^{2}$

China began its economic reforms in 1979. In the pre-reform planned economy, private business contracts were of no use. As the reform became more extensive and the market began to play a more important role in business, both formal and relational contracts came into use and became prevalent. According to the World Bank survey, in 2000, there were some $80 \%$ of the Chinese firms having formal contracts with their clients or suppliers and the rest (20\%) relying on relational contracts. ${ }^{3}$ Through an

\footnotetext{
* Corresponding author. School of Economics and Finance, The University of Hong Kong, Pokfulam, Hong Kong. E-mail address: larryqiu@hku.hk (L.D. Qiu).

${ }^{1}$ In law, a contract is "an agreement which is legally enforceable or legally recognized as creating a duty" (Atiyah, 1989, p. 40). In contrast, some economists define a contract as an agreement that "specifies a mechanism or game between the principal and agent, including expected actions and beliefs, even when these cannot be verified in court” (MacLeod, 2002, p. 217).

${ }^{2}$ In this paper, we use the term formal contract to include written contract and explicit contract, and relational contract to include implicit contract and oral contract.

${ }^{3}$ It is incorrect to think that not having formal contracts is a phenomenon of the incomplete market reforms in China. Relational contracts are important in Japanese businesses (Asanuma, 1989). Even in the United States, firms do not always have formal contracts with their clients and suppliers. "Businessmen often prefer to rely on 'a man's word' in a brief letter, a handshake, or 'common honesty and decency”' (Macaulay, 1963, p. 58). According to Macaulay's (1963) survey in the United States, the percentages of orders where no written agreement on terms and conditions was reached or no formal contract was formed were as follows $75.0 \%$ in $1953,69.4 \%$ in $1954,71.5 \%$ in 1955 and 59.5\% in 1956. Many recent studies (e.g., Baker et al., 2002) also stress the prevalence of relational contracts between firms and in business dealings.
} 
econometric analysis based on this rich data set, we have found that a Chinese firm is more likely to have formal contracts with its clients/suppliers if it is a large firm in its industry/market and if the firm's clients/suppliers are located in a different city from the firm's location. While a firm tends to have formal contracts with its clients in the case where the number of clients is small, it tends to have formal contacts with its suppliers if the number of suppliers is large. In contrast, relational contracts are adopted by firms in the opposite cases.

Our paper makes two contributions to the economic literature. First, it provides an empirical analysis on contracting behavior. Although there is a very large and well-developed literature on contract theory (see Bolton and Dewatripont, 2005), the empirical literature on contracts is still relatively new and small. ${ }^{4}$ This paper makes a contribution to this nascent empirical literature by identifying conditions and situations in which firms adopt formal contracts or those in which they adopt relational contracts.

The paper makes the second contribution to the understanding of economic and business behavior of Chinese firms. Most of the literature on Chinese economy focuses on explanations for the unprecedented growth of the Chinese economy. In this paper, we are particularly interested in understanding the contracting behavior of Chinese firms.

A lot of theoretical questions/issues with regard to contracts have been nicely treated, analyzed, and surveyed by Bolton and Dewatripont (2005) in their textbook. Generally, formal contracts are contracts which are written and enforceable by the court, while relational contracts are implicit and rely on self-enforcing provisions. Our study provides some evidence on when to choose formal contracts and when to choose relational contracts. Formal contracts attempt to specify terms and conditions so as to allow the parties evolved to achieve efficient transactions. However, sometimes firms feel that it is not necessary to have formal contracts or it is too costly to have them. ${ }^{5}$ Moreover, relational contracts can also help achieve more efficient outcomes in many situations. Important contributions in this area include, among others, Shapiro and Stiglitz (1984), Bull (1987), Baker, Gibbons and Murphy (1994, 2002), and Levin (2003). Some theoretical papers explicitly examine the trade-offs between formal and relational contracts, for example, MacLeod and Malcomson (1998), Pearce and Stacchetti (1998), Baker et al (1994), Corts (2007), and Zanarone (2007). These papers examine standard agency models and focus entirely on the ability of formal and relational contracts to solve incentive problems. Our empirical study is not built on any specific model. It identifies empirically some important factors that affect a firm's choice between formal contracts and relational contracts, for whatever reasons. We rely on various existing models to provide explanations for our findings.

Based on interviews and case studies, Macaulay (1963) presents findings concerning when contracts are and are not used and provides a tentative explanation for his findings. In particular, he argues that it is not uncommon that businesses do not always rely on formal contracts. There are many reasons for not having formal contracts. First, in many situations, there is little room for honest misunderstandings or good faith differences of opinion about the nature and quality of the firms' products/services (e.g., the goods/services are very standardized). Second, having a formal contract means there is legal protection when defaults occur. However, it is "often thought unnecessary because there are many effective non-legal sanctions" (Macaulay, 1963, p. 63) available and the use of legal sanctions "may have, or may be thought to have, undesirable consequences" (Macaulay, 1963, p. 64). Third, a firm and its distributors "often prefer to rely on 'a man's word' in a brief letter, a handshake, or 'common honesty and decency"” (Macaulay, 1963, p. 58). Hence, handshake plus a brief letter or phone call for an order is equivalent to a binding contract. Similar to Macaulay (1963), we investigate when to have formal or relational contracts. However, the two papers are significantly different. Macaulay (1963) is a classic piece of "empirical" work on contracting. His findings are based on a small sample of interviews (68 businessmen and lawyers). Although very insightful, his "research is only the first phase in a scientific study" (Macaulay, 1963, p. 55). In the present paper, we use a survey of 1500 firms with data on many dimensions (e.g., a firm's size, location, etc) to conduct an econometric analysis on factors that influence a firm's contracting decision. Hence, we can systematically analyze contracting variables and their significance on a firm's contracting decision.

McMillan and Woodruff (1999a) use the 1995-97 survey of privately owned manufacturing firms in Vietnam to analyze contracting and dispute preventing behavior in the absence of court enforcement. They find that manufacturers tend to use formal contracts when a very large fraction of the manufacturer's sales to customers involves goods produced to order, when more than half of the manufacturer's sales are made to the customer, and when the customer is located in a different city. Their survey includes questionnaire answers from 259 managers and in-depth interviews with 17 firms. Like McMillan and Woodruff (1999a), we examine contracting behavior of firms in a transitional economy, China. Unlike them, however, we use a much larger data set in our study, and, more importantly, as a result of that, our results are obtained based on an econometric analysis as opposed to their descriptive analysis. Furthermore, we explore a different set of factors that affect a firm's contracting decisions. ${ }^{6}$

Three important results are obtained from our data. First, firms are more likely to have formal contracts if they are larger in their own industries/markets, and more likely to have relational contracts if they are smaller. This finding is consistent with the

\footnotetext{
${ }^{4}$ For review of the empirical literature, see Lyons (1996) for the earlier empirical literature on efficient contracts and Boerner and Macher's (2002) for the more recent empirical literature on transaction cost economics.

5 Battigalli and Maggi (2002) describe the following costs of writing contracts: (i) the cost of figuring out the relevant contingencies and obligations; (ii) the cost of thinking how to describe them; (iii) the cost of time needed to write the contract and the cost of lawyers. They derive results of how the writing cost and other factors affect the nature (i.e., rigidity and discretion) of the optimal incomplete contract. However, we can see the possibility that if the cost of writing contracts is too high, the firms will choose not to have them.

${ }^{6}$ In another paper, through econometric analysis, McMillan and Woodruff (1999b) show that contracting among Vietnamese firms is based on ongoing relations. The type of contract they focus on is the trade credits that a firm grants to its customers. They find that the offering of trade credits depends on the buyer's ability to locate alternative suppliers, the seller's gathering of information about the buyer's reliability, and the seller's membership in a business network. Our work is about general business contracts. We find that contracting is influenced by a firm's size, the market competition and the firm's location.
} 
idea that writing formal contracts is costly (Battigalli and Maggi, 2002). Note that the fixed writing cost is relatively smaller for a large firm than a small firm because the former has a larger transaction which the contract governs.

Second, firms are more likely to have formal contracts with their clients (suppliers) if the number of clients (suppliers) is smaller (larger), and they are more likely to use relational contracts in the opposite situation. The effect of the number of clients/ suppliers on the firm's contracting decision may be related to the hold-up problem. In this respect, our finding seems to support the idea that when there are more suppliers, the firm uses formal contract to assure the suppliers that it will not switch so as to encourage specific investments; but when it faces the clients, it prefers flexibility (or to avoid being held up) when there are more clients. Another possible reason for the contracting result with suppliers is related to the vertical integration. With more suppliers, the firm is more likely to be less vertically integrated. Then, the upper stream supply becomes more critical to the firm's production and the firm would want to use formal contracts with its suppliers to secure input supply.

Third, firms are more likely to have formal contracts with their business partners (clients or suppliers) if they are located in different cities, and they are more likely to adopt relational contracts if they are located in the same city. ${ }^{7}$ This empirical finding is consistent with McMillan and Woodruff's (1999a) observation based on simple statistics. In the case of relationship with its clients, a firm generally has more information about clients within the same city than about those far away. Therefore, the firm does business with trustworthy local clients without formal contracts, but uses contracts to secure business with less-known, faraway clients. Location is also related to risk. If the local clients do not honor their oral agreements (informal contracts) with a firm, they will not only lose their future business with the firm, but also business with other firms. That is, there will be local community punishment for dishonest behavior. However, if clients are located in a far-away city, other firms in that city would be less likely to learn about this misbehavior with a firm not located in the same city. Hence, the probability of facing community punishment is lower, which increases the clients' incentives to breach oral agreements. Hence, formal contracts are used to deter reneging with geographic distance between firms and clients. The same argument applies to a firm's relationship with its suppliers.

The rest of the paper is organized as follows. In Section 2, we establish the empirical model. Section 3 describes the data. The results based on contracting behavior between firms and their clients are provided and explained in Section 4. In Section 5, we explore contracts between firms and their suppliers. Section 6 concludes the paper.

\section{Empirical specifications}

This paper attempts to investigate empirically factors affecting a firm's decision to have contracts with its clients and suppliers. To this end, we establish a stylized reduced-form model in which the decision on contracting (having a formal contract or not) is the dependent variable and factors which potentially affect contracting decisions are independent variables. However, many of those independent variables are not directly measurable. Researchers have tried hard to find proxies for them. Our strategy is to focus on a few of them (or some new ones) for which we can find good proxies from our data set. This serves as a complement to the existing empirical literature which mainly focuses on specific industries and firms. Fewer proxies are available when a larger set of firms are included, as in our study.

One of the factors that we are interested is firm size and the other is the number of clients. These are basic features of a firm and its business relationship, which may affect its contracting decision. In addition, McMillan and Woodruff (1999a) observe that firms are more likely to have written contracts with their customers when the customers are located in a different city. The reason is that when the customers are located in a different city from the manufacturer, the manufacturer faces a greater reneging risk and therefore will use written contracts to protect transactions. The effect of this geographic variable has never been formally tested. We include it in our model.

In light of the above discussion, we propose the following basic econometric model

$$
C_{i}=\alpha_{0}+\alpha_{1} \text { SIZE }_{i}+\alpha_{2} \text { DCITY }_{i}+\alpha_{3} \text { CLIENT }+\alpha_{4} \text { IndDummy }+\alpha_{5} \text { CityDummy }+\varepsilon_{i},
$$

where the dependent variable, $C_{i}$, is the binary variable indicating whether or not firm $i$ has formal contracts with its clients ( 1 for having formal contracts, and zero for not (or having relational contracts)), $S_{Z} E_{i}$ is the logarithm of the size of firm i, DCITY $i$ is a location variable describing the geographic distribution of firm $i$ 's clients, CLIENT $_{i}$ is the logarithm of the number of clients firm i

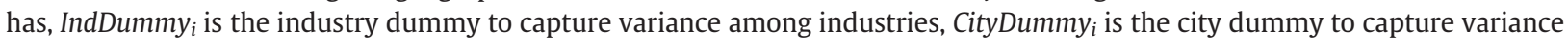
among cities, $\alpha_{j}(j=0, \ldots 5)$ are parameters to be estimated, and $\varepsilon_{i}$ is an error term. As we will describe later, we focus on one year's data (Year 2000) of contracting, and hence we estimate Eq. (1) by a simple logit model. We apply the robust method $a$ la Huber which down weights the sample outliers to make the estimation less sensitive to measurement errors, and use White-corrected standard errors to deal with potential heteroskedasticity.

\section{Data}

Our dataset is constructed based on the World Bank's survey of enterprises in China. The survey covers 1500 firms across five major cities and ten industries. The five cities are Beijing, Chengdu, Guangzhou, Shanghai and Tianjing, and the ten industries

\footnotetext{
7 In their historical analysis on trade laws, Milgrom, North, and Weingast (1990) pointed out the importance of location for introducing a new law. When traders were located in different locations, punishment on cheating would be difficult to enforce. The Law Merchant could help restore trade by disseminating information.
} 
include five in the services sector (accounting, advertising and marketing, business logistics, communication and information technology) and five in the manufacturing sector (apparel and leather goods, consumer goods, electronic equipment, electronic components and vehicles and vehicle parts). While the number of surveyed firms is evenly distributed across the five cities, there are more manufacturing firms (998 in total) than service firms (502 in total). The survey covers the period of 1998-2000, but most contract-related questions concern year 2000 only. Thus, our empirical examination below focuses on year 2000.

Let us confine our data description to proxies for the variables in Eq. (1). The summary statistics of the variables and their measurements are presented in Table 1.

First of all, we need to identify a dummy variable to represent the dependent variable, $C_{i}$. In the survey, each firm is asked the following question: "Generally, do you enter into written contracts with your clients?" We assign the value of 1 to the contract dummy, $C_{i}$, if the answer is yes, and 0 otherwise. From the dataset, we find that on average $90.1 \%$ of the surveyed firms entered into formal contracts with their clients between 1998 and 2000. The percentage of firms using formal contracts in the manufacturing sector is higher than that in the services sector (92.4\% versus $85.5 \%$ ).

We next turn to the variable that captures a firm's size. SIZE $i$ is proxied by firm $i$ 's total fixed assets in year $2000 .^{8}$ In our dataset, the average size of the firms is about RMB 195.95 million (or US\$23.72 million, at the exchange rate at that time), with the variance up to RMB 1613.6 million. We have also tried to use total employment and total sales, respectively, to measure SIZE $E_{i}$ The qualitative results do not change. Hence, we only report the case of total fixed assets as $\operatorname{SIZE}_{i}$ in this paper.

About the clients, the survey asks each firm how many clients it has in its main business line. This is CLIENT in Eq. (1). In our data, manufacturing firms on average have 399 clients and services firms have $3619 .{ }^{9}$ The survey also asks each firm where its clients are located in 2000. DCITY is a location dummy variable, which equals 1 if firm i has 30\% or more clients located outside the city where firm $i$ 's main business line is located, and 0 otherwise. The choice of the critical level, 30\%, seems quite arbitrary here, but the qualitative result is robust to changes of this level. About $60.3 \%$ of the firms have more than $30 \%$ of their clients outside their main cities. These figures are $75.2 \%$ for manufacturing firms and 30.9\% for services firms. Finally, as mentioned earlier, firms are from five cities and ten industries, which define the industry dummy and city dummy, respectively.

\section{Empirical results based on contracts with clients}

We run Logit regressions based on Eq. (1) and report the regression results in column 1 of Table 2. We then run other regressions to check the robustness and report those results in other columns of Table 2. Note that we utilize White-corrected standard errors to deal with potential heteroskadasticity, and we include industry and city dummies in our regressions to control the variation among industries and cities. However, to save space, we do not report their coefficients in this table.

\subsection{Basic results}

From column 1 of Table 2, which is derived from Eq. (1), we find a significantly positive effect of firm size on formal contracts. That is, other things the same, larger firms tend to have formal contacts with their clients while smaller firms tend to have relational contacts. Note that the same amount of total assets in different industries means different sizes. However, our regression includes industry dummy which helps correct this problem. Hence, total asset is a good measurement of firm size. One explanation for this finding is that writing formal contracts is costly (Battigalli and Maggi, 2002). The fixed cost is relatively smaller for a large firm than a small firm because the former has a larger transaction which the contract governs and so relatively less costly for larger firms to write formal contracts.

The coefficient of the number of clients is negative and statistically significant. There are two possible reasons for this result. First, the fact that a firm has a larger number of clients is often associated with the case where the firm's products are more standard ones and so contracts are less desirable. In response to Macaulay's (1963, p. 62) question on why they do not have formal contracts with their clients, managers say, "in most situations contract is not needed ... because usually there is little room for honest misunderstandings or good faith differences of opinion about the nature and quality of a seller's performance". Second, the firm prefers flexibility (or to avoid being held up) when there are more clients. Note that McMillan and Woodruff (1999a) find that a manufacture tends to have formal contracts with its customers when a larger fraction of sales are made to them. Although we do not have the variable similar to McMillan and Woodruff (1999a), our findings are consistent because the case of a fewer clients is often associated with higher concentration to each client.

The coefficient of the dummy for location is found to be positive and statistically significant. In other words, we find clear evidence that firms with a considerable percentage of their clients outside the firm's main business location are more likely to use formal contracts in their businesses while others are more likely to adopt relational contracts. Hence, location matters to contracting. This empirical finding is consistent with McMillan and Woodruff's (1999a) observation based on simple statistics. There are a number of plausible explanations (also see McMillan and Woodruff, 1999a). First, geography is related to uncertainty and asymmetric information. Having a formal contract is costly and if a firm is sure that its clients are trustworthy, it can avoid contracting costs. In general a firm has more information about clients within the same city than about those far away. Therefore,

\footnotetext{
${ }^{8}$ A firm's fixed assets in the survey are defined to include buildings, production machinery and equipment, IT technology, office equipment, cars, vans and trucks, and others.

${ }^{9}$ In our survey, the definition of clients includes all kinds of buyers. Thus, the number of clients could be quite large if firms, particularly services firms, sell their products directly to their customers.
} 
Table 1

Summary statistics.

\begin{tabular}{|c|c|c|c|c|c|c|c|c|c|c|}
\hline \multirow[t]{2}{*}{ Variables } & \multirow[t]{2}{*}{ Unit } & \multicolumn{3}{|c|}{ Full sample } & \multicolumn{3}{|c|}{ Manufacturing firms } & \multicolumn{3}{|c|}{ Service firms } \\
\hline & & Obs. & Mean & Stdev. & Obs. & Mean & Stdev. & Obs. & Mean & Stdev. \\
\hline \multicolumn{11}{|l|}{ Dependent variables } \\
\hline $\begin{array}{l}\text { Formal contracts } \\
\text { with clients }\end{array}$ & $\operatorname{Dummy}(0-1)$ & 1500 & 0.901 & 0.30 & 998 & 0.924 & 0.27 & 502 & 0.855 & 0.35 \\
\hline $\begin{array}{l}\text { Formal contracts } \\
\text { with suppliers }\end{array}$ & $\operatorname{Dummy}(0-1)$ & 1500 & 0.815 & 0.39 & 998 & 0.877 & 0.33 & 502 & 0.693 & 0.46 \\
\hline \multicolumn{11}{|l|}{ Independent variables } \\
\hline \multicolumn{11}{|l|}{$\begin{array}{l}\text { Firm production and } \\
\text { performance }\end{array}$} \\
\hline Capital assets & $1000 \mathrm{RMB}$ & 1500 & 195947.1 & 1613641 & 998 & 111273.6 & 530010.5 & 502 & 364282 & 2681236 \\
\hline SOE dummy & $\operatorname{Dummy}(0-1)$ & 1500 & 0.21 & 0.408 & 998 & 0.19 & 0.396 & 502 & 0.24 & 0.429 \\
\hline \multicolumn{11}{|l|}{ Relationship with clients } \\
\hline Having outside city clients & $\operatorname{Dummy}(0-1)$ & 1500 & 0.603 & 0.49 & 998 & 0.752 & 0.43 & 502 & 0.309 & 0.46 \\
\hline Number of clients & Number & 1447 & 1444.9 & 8986.9 & 977 & 399.2 & 3196.7 & 470 & 3618.7 & 14857.2 \\
\hline $\begin{array}{l}\text { Business duration } \\
\text { with clients }\end{array}$ & $\operatorname{Dummy}(0-5)$ & 1499 & 3.82 & 1.38 & 998 & 4.05 & 1.26 & 501 & 3.36 & 1.49 \\
\hline \multicolumn{11}{|l|}{ Relationship with suppliers } \\
\hline Having outside city suppliers & $\operatorname{Dummy}(0-1)$ & 1500 & 0.621 & 0.49 & 998 & 0.703 & 0.46 & 502 & 0.458 & 0.50 \\
\hline Number of suppliers & Number & 1418 & 49.8 & 118.86 & 981 & 55.4 & 108.56 & 437 & 37.4 & 138.58 \\
\hline $\begin{array}{l}\text { Business duration with } \\
\text { suppliers }\end{array}$ & Dummy(0-5) & 1473 & 3.76 & 1.40 & 996 & 4.03 & 1.26 & 477 & 3.20 & 1.50 \\
\hline Vertical integration & Ratio & 1307 & 0.49 & 0.31 & 982 & 0.59 & 0.25 & 325 & 0.17 & 0.26 \\
\hline \multicolumn{11}{|l|}{ Competition } \\
\hline Number of competitors & Number & 1384 & 307.6 & 1666.6 & 916 & 175.2 & 1085.5 & 468 & 566.7 & 2411.4 \\
\hline $\begin{array}{l}\text { Percent of competitors in the } \\
\text { same city }\end{array}$ & Percent & 1325 & 40.35 & 38.72 & 883 & 28.74 & 33.39 & 442 & 63.53 & 38.26 \\
\hline
\end{tabular}

the firm does business with trustworthy local clients without formal contracts, but uses formal contracts to secure business with less-known, far-away clients. Second, geography is related to reneging risk. If the local clients do not honor their oral agreements (informal contracts) with a firm, they will not only lose their future business with the firm, but also business with other firms. That is, there will be local community punishment for dishonest behavior. However, if clients are located in a far-away city, other firms in that city would be less likely to learn about this misbehavior with a firm not located in the same city. Hence, the probability of facing community punishment is lower, which increases the clients' incentives to breach oral agreements. Hence, formal contracts are used to deter reneging with geographic distance between firms and clients. ${ }^{10}$

\subsection{Robustness checks}

We run six other regressions to investigate other factors that might potentially have impacts on firms' contracting behavior. We also check whether or not adding those factors into our basic model, Eq. (1), will change the main findings (model 1 in Table 2).

Business duration. To save contracting costs, firms may choose relational contracts over formal contracts with their clients if they trust each other. Trust can be built by having long-term business relations. On the other hand, if firms have long-term business relations with their clients, they can rely on self-enforcing relational contracts to substitute for court-enforcing formal contracts (McMillan and Woodruff, 1999a). ${ }^{11}$ It is often argued that Japanese automobile manufacturers use relational contracts with their parts suppliers since they have long-term relationships (Asanuma, 1989). We therefore create a dummy variable for the average duration of relationships between firms and their clients. The variable for business duration takes a value from 1 to 5 . It is equal to 1 when the relationship has lasted less than one year, 2 for one-two years, 3 for two-three years, 4 for three-four years, and 5 for more than four years. As shown in Table 1, the average of this duration dummy variable for the firms from our dataset is 3.82, with the manufacturing firms having slightly longer relationships than service firms have ( 4.05 versus 3.36). ${ }^{12}$ We then add this business duration dummy to the basic model and report results in the second column of Table 2 (model 2). We find a negative sign for business duration, as expected, but the coefficient is not significant. More importantly, the results of other variables in model 1 remain unchanged.

It is reasonable to conjecture that firms find their clients in the same city first and then extend their business to other cities. If this conjecture is correct, then our result that firms tend to have written contracts if their major clients are located in other cities

\footnotetext{
${ }^{10}$ Klein (1996) has examined contacts with some geographic issues. In his Alcoa-Essex case, Essex located its cable fabrication plant adjacent to an Aloca aluminum production facility, which increases Aloca's holdup potential. Contract can be used to mitigate the hold-up problem. In this example, location is a specific investment related to hold-up. In our case, location is more related to information, risk, punishment, etc. The impact of the geographic factors is very different in these two papers.

11 Battigalli and Maggi (2003) present a theoretical analysis of relational contracts in long-term relationships.

12 Note that the larger this average value is, the longer the average duration of business relationships the firms have with their clients. However, it should be pointed out that these average numbers are not exactly the number of years of business duration, due to our special specification of this dummy variable.
} 
Table 2

The logit estimations on contracts with clients.

\begin{tabular}{|c|c|c|c|c|c|c|c|}
\hline \multicolumn{8}{|c|}{ Dependent variable: formal contracts with clients } \\
\hline & Model 1 & Model 2 & Model 3 & Model 4 & Model 5 & Model 6 & Model 7 \\
\hline Ln (firm size) & $\begin{array}{l}0.279^{* * * *} \\
(0.045)\end{array}$ & $\begin{array}{l}0.280^{* * * *} \\
(0.048)\end{array}$ & $\begin{array}{l}0.279^{* *} \\
(0.046)\end{array}$ & $\begin{array}{l}0.271^{* * * *} \\
(0.045)\end{array}$ & $\begin{array}{l}0.281^{* * *} \\
(0.051)\end{array}$ & $\begin{array}{l}0.205^{* * *} \\
(0.043)\end{array}$ & $\begin{array}{l}0.281^{* * * *} \\
(0.045)\end{array}$ \\
\hline Outside city clients & $\begin{array}{l}0.594^{* * *} \\
(0.199)\end{array}$ & $\begin{array}{l}0.593^{* * *} \\
(0.200)\end{array}$ & $\begin{array}{l}0.593^{* * *} \\
(0.198)\end{array}$ & $\begin{array}{l}0.550^{* * * *} \\
(0.202)\end{array}$ & $\begin{array}{l}0.627^{* * * *} \\
(0.223)\end{array}$ & $\begin{array}{l}0.712^{* * * *} \\
(0.198)\end{array}$ & $\begin{array}{l}0.005^{*} \\
(0.003)\end{array}$ \\
\hline Ln (number of clients) & $\begin{array}{l}-0.086^{* *} \\
(0.043)\end{array}$ & $\begin{array}{l}-0.086^{* *} \\
(0.044)\end{array}$ & $\begin{array}{l}-0.085^{* *} \\
(0.043)\end{array}$ & $\begin{array}{l}-0.084^{* * *} \\
(0.043)\end{array}$ & $\begin{array}{l}-0.105^{* *} \\
(0.046)\end{array}$ & $\begin{array}{l}-0.135^{* * * *} \\
(0.046)\end{array}$ & $\begin{array}{l}-0.086^{* *} \\
(0.043)\end{array}$ \\
\hline Business duration with clients & & $\begin{array}{l}-0.006 \\
(0.076)\end{array}$ & & & & & \\
\hline SOE dummy & & & $\begin{array}{l}-0.028 \\
(0.223)\end{array}$ & & & & \\
\hline Export dummy & & & & $\begin{array}{l}0.216 \\
(0.286)\end{array}$ & & & \\
\hline Ln (number of competitors) & & & & & $\begin{array}{l}-0.068 \\
(0.056)\end{array}$ & & \\
\hline Same city competitors & & & & & $\begin{array}{l}0.003 \\
(0.003)\end{array}$ & & \\
\hline Service sector dummy & & & & & & $\begin{array}{l}0.011 \\
(0.202)\end{array}$ & \\
\hline Constant & $\begin{array}{l}0.625 \\
(0.529)\end{array}$ & $\begin{array}{l}0.643 \\
(0.558)\end{array}$ & $\begin{array}{l}0.624 \\
(0.559)\end{array}$ & $\begin{array}{l}0.274 \\
(0.553)\end{array}$ & $\begin{array}{l}0.900 \\
(0.660)\end{array}$ & $\begin{array}{l}1.062^{* *} \\
(0.467)\end{array}$ & $\begin{array}{l}0.727 \\
(0.539)\end{array}$ \\
\hline Observations & 1435 & 1435 & 1435 & 991 & 1267 & 1435 & 1425 \\
\hline Pseudo- $R^{2}$ & 0.15 & 0.15 & 0.15 & 0.18 & 0.17 & 0.10 & 0.14 \\
\hline
\end{tabular}

Notes:

1) ***,** and * denote $1 \%, 5 \%$ and $10 \%$ significant levels, respectively.

2) The numbers in the brackets are White-corrected standard errors.

3) Industry and city fixed effects are controlled.

could be subject to a different interpretation: they have not yet built up trust since the duration of their relationship is short. However, this is not a valid argument. First, as we just showed, the impact of business duration on the contract decision is not significant. Second, as reported in column 2 of Table 2, the results obtained in the preceding section, including the location result, remain unaffected by introducing the duration dummy. Our finding seems to support some recent arguments for community punishment, as opposed to long-term relationship, to support cooperation. ${ }^{13}$

Ownership. The Chinese economy has a mix of private ownership and state ownership. Contracts rarely existed (they were indeed not necessary) in the past when the economy was purely state run. If state-owned firms still continue the tradition of not entering into contracts with their clients, we should exclude them from the test. However, many firms in China now are partially private and partially state owned. To avoid eliminating too many data points from the test, we construct model 3 by adding to our basic model 1 a new variable, SOE Dummy, which is 1 if the firm is a state-owned enterprise (SOE) and 0 otherwise. As shown in Table 1, around 21\% firms in the survey are SOEs. If private firms are more likely than SOEs to have formal contracts, we expect that the parameter of this dummy variable will be negative. We run the regression based on model 3 and find that the effect is negative but statistically insignificant: there is no support for the above conjecture. Moreover, the signs and significance of the coefficients for the other variables remain the same as in model 1, with very small changes in their magnitudes.

Exports. If a firm has a considerable percentage of its clients located outside the city of its main business line, it could be the case where the clients are located in other Chinese cities or in foreign countries (i.e., the firm exports its products or services). One may expect that formal contracts may be required for exports. If that is the case and if a firm's outside-the-city clients are mainly overseas clients, then the contract geography result would be too straightforward and the explanations given above for contract geography would not be relevant. To check this, we re-estimate model 1 by adding an export dummy which is equal to one if the firm has overseas clients and zero otherwise. The results are reported in model 4 of Table 2 . Note that the basic results of model 1 are unaltered, with the coefficient of the export dummy positive (as expected), but not statistically significant.

- Competition. How will the number of competitors affect contracting? We might expect that if a firm faces severe competition, it may want to secure its business relationships with its clients through formal contracts. To test this hypothesis, we introduce two competition variables into the model: one is the number of competitors in the firms' main business, and the other is the percentage of the competitors located in the same city of the firm's main business line. Note that these two variables are obtained based on reports by the firms' managers and are not necessarily the true values of the industries. Model 5 incorporates

\footnotetext{
${ }^{13}$ The referee correctly points out that the business duration is endogenous to the match between the firm and its clients. Thus, the earlier-discussed causality may not exist.
} 
these two variables into model 1 . We run the regression of model 5 and report the results in Table 2 . The coefficients of these two variables are not statistically significant while other results remain unchanged.

- Sectorial differences. The regression results may be different between services sector and manufacturing sector. However, we have no prior knowledge of how they are different. On the one hand, a firm in services sector tends to have many more clients than a firm in manufacturing sector, especially when the manufacturing products are distributed by intermediate agents. This difference suggests that services firms use formal contracts less. On the other hand, services products are less standard and transparent than manufacturing products. This difference suggests that formal contracts can be used to describe the features of services products to avoid misunderstandings between the firms and their clients. In model 6 , we use a dummy variable to represent the services sector in the regression to factor out the differences between the two sectors. As reported in Table 2, the parameter of the dummy for services firms is statistically insignificant, which implies that there is no significant difference in the contracting behavior between manufacturing and services firms. Introducing the services sector dummy does not affect the basic results either. However, we should point out that we have included industry dummies, which have captured contracting differences among different industries. The result here simply indicates that contracting behavior could be significantly different among different industries, but not between the two sectors: manufacturing and services.

- Location Ratio. Finally, we replace the firm's location dummy by its ratio of outside-the-city clients to total clients and rerun the basic regression, called model 7. This is a test of whether or not the contract geography feature is sensitive to the critical level of $30 \%$. In our sample, on average, each firm has $49.9 \%$ of its clients outside its city, and this percentage for manufacturing firms is much higher than that for services firms (62.5\% versus $24.9 \%$ ). As shown in Table 2, we again find that formal contracts are positively and significantly associated with firm size and outside-the-city clients, and negatively and significantly associated with the number of clients.

In summary, introducing factors that potentially affect contracting into model 1 does not alter the basic results about the effects of firm size, number of clients, and location on contracting. Furthermore, these "potential" candidate variables as contract determinants do not have statistically significant effects on firms' contract decisions.

\section{Contracts with suppliers}

Our survey also contains data on firms' contracting information with their suppliers. As reported in Table $1,81.5 \%$ of the firms generally use formal contracts with their suppliers, which is around ten percent lower than the percentage of formal contracts used with their clients. And the percentage of firms using formal contracts in the manufacturing sector is again higher than that in the services sector ( $87.7 \%$ vs. $69.3 \%)$. Also, we can see that the average number of suppliers is around 50 , much smaller than the average number of clients (1445). Meanwhile, $62.1 \%$ of the surveyed firms have more than $30 \%$ of their suppliers outside the city where their main business is located. The percentages of firms with outside city suppliers in the manufacturing and services sectors are $70.3 \%$ and $45.8 \%$, respectively. Lastly, firms on average have 3.76 years business relationships with their suppliers.

We follow a similar empirical strategy used in examining the contracting decision with clients to investigate the contracting decision with suppliers. The regression results are reported in Table 3.

\subsection{Basic results}

Corresponding to Eq. (1), we construct the basic econometric model for contracting with suppliers as

$$
C_{i}=\beta_{0}+\beta_{1} \text { SIZE }_{i}+\beta_{2} \text { DCITY }_{i}+\beta_{3} \text { SUPPLIER }_{i}+\beta_{4} \text { IndDummy }_{i}+\beta_{5} \text { CityDummy }_{i}+\varepsilon_{i},
$$

where the dependent variable, $C_{i}$, is the binary variable indicating whether or not firm $i$ has formal contracts with its suppliers, $S_{I Z E_{i}}$ is the logarithm of the size of firm $i, D C I T Y_{i}$ is a location variable describing geographic distribution of firm $i$ 's suppliers, SUPPLIER $R_{i}$ is the logarithm of the number of suppliers firm $i$ has, the two dummies, IndDummy $y_{i}$ and CityDummy, are defined the same as in Eq. (1), $\beta_{j}(j=0, \ldots 5)$ are parameters to be estimated, and $\varepsilon_{i}$ is an error term.

Regression results based on Eq. (2) are reported as model 1 in Table 3. First, we find that firm size is significantly and positively correlated with formal contracts.

Second, the dummy for outside-the-city supplier is again significantly and positively correlated to the firms' decisions on using formal contracts. That is, that location matters in contracting is supported by the firms' relationships with suppliers as well.

Third, we find that formal contracts and the number of suppliers are positively and significantly correlated. This result is in sharp contrast to the effects of the number of clients on contracts, which is significantly negative. We here offer some plausible explanations for this result. Our first idea is from the perspective of vertical industrial integration. To some extent, the number of suppliers that a firm has reflects the firm's dependence on outside suppliers of inputs (raw materials and intermediate goods). The more suppliers the firm has, the greater the possibility that the firm is less vertically integrated. That is, the upper stream supply becomes more critical to the firm's production. Therefore, the firm would want to use formal contracts with its suppliers to secure input supply and thus production. The second plausible explanation is based on the risk/information associated with the number of suppliers. With more suppliers, it is less possible that the firm knows all suppliers well and hence the firm faces higher risk that some suppliers will fail to provide the needed inputs to the firm. However, if those inputs are crucial to production, a breakdown in the firm's production becomes more likely. The firm can use formal contracts with its suppliers to lower this risk. Finally, when 
Table 3

The logit estimations on contracts with suppliers.

\begin{tabular}{|c|c|c|c|c|c|c|c|}
\hline \multicolumn{8}{|c|}{ Dependent variable: formal contracts with suppliers } \\
\hline & Model 1 & Model 2 & Model 3 & Model 4 & Model 5 & Model 6 & Model 7 \\
\hline Ln (firm size) & $\begin{array}{l}0.312^{* * *} \\
(0.043)\end{array}$ & $\begin{array}{l}0.309^{* * * *} \\
(0.044)\end{array}$ & $\begin{array}{l}0.316^{\text {*** }} \\
(0.044)\end{array}$ & $\begin{array}{l}0.303^{* * *} \\
(0.044)\end{array}$ & $\begin{array}{l}0.311^{* * *} \\
(0.047)\end{array}$ & $\begin{array}{l}0.247^{* * * *} \\
(0.039)\end{array}$ & $\begin{array}{l}0.311^{\text {*** }} \\
(0.043)\end{array}$ \\
\hline Outside city suppliers & $\begin{array}{l}0.885^{* * *} \\
(0.189)\end{array}$ & $\begin{array}{l}0.879 * * * \\
(0.191)\end{array}$ & $\begin{array}{l}0.883^{* * *} \\
(0.189)\end{array}$ & $\begin{array}{l}0.856^{* * *} \\
(0.193)\end{array}$ & $\begin{array}{l}0.907^{* * *} \\
(0.212)\end{array}$ & $\begin{array}{l}1.111^{* * *} \\
(0.174)\end{array}$ & $\begin{array}{l}0.012^{\text {*** }} \\
(0.003)\end{array}$ \\
\hline Ln (number of suppliers) & $\begin{array}{l}0.187^{* * *} \\
(0.072)\end{array}$ & $\begin{array}{l}0.186^{* * *} \\
(0.072)\end{array}$ & $\begin{array}{l}0.186^{\text {*** }} \\
(0.073)\end{array}$ & $\begin{array}{l}0.188^{* *} \\
(0.072)\end{array}$ & $\begin{array}{l}0.149^{* *} \\
(0.074)\end{array}$ & $\begin{array}{l}0.197^{* * *} \\
(0.069)\end{array}$ & $\begin{array}{l}0.196^{\text {**** }} \\
(0.072)\end{array}$ \\
\hline Business duration with suppliers & & $\begin{array}{l}0.021 \\
(0.066)\end{array}$ & & & & & \\
\hline SOE dummy & & & $\begin{array}{c}-0.147 \\
(0.212)\end{array}$ & & & & \\
\hline Export dummy & & & & $\begin{array}{l}0.218 \\
(0.259)\end{array}$ & & & \\
\hline Ln (number of competitors) & & & & & $\begin{array}{c}-0.003 \\
(0.049)\end{array}$ & & \\
\hline Same city competitors & & & & & $\begin{array}{l}0.001 \\
(0.003)\end{array}$ & & \\
\hline Service sector dummy & & & & & & $\begin{array}{l}-0.182 \\
(0.176)\end{array}$ & \\
\hline Constant & $\begin{array}{l}-1.271^{* *} \\
(0.496)\end{array}$ & $\begin{array}{l}-1.331^{* *} \\
(0.535)\end{array}$ & $\begin{array}{l}-1.286^{* *} \\
(0.497)\end{array}$ & $\begin{array}{l}-1.339^{* *} \\
(0.533)\end{array}$ & $\begin{array}{l}-1.199 * \\
(0.598)\end{array}$ & $\begin{array}{l}-1.190^{* *} \\
(0.433)\end{array}$ & $\begin{array}{l}-1.2191^{* *} \\
(0.5214)\end{array}$ \\
\hline Observations & 1408 & 1407 & 1408 & 924 & 1240 & 1408 & 1406 \\
\hline Pseudo- $R^{2}$ & 0.25 & 0.26 & 0.26 & 0.22 & 0.26 & 0.18 & 0.25 \\
\hline
\end{tabular}

Notes:

1) ***, ${ }^{* *}$ and $*$ denote $1 \%, 5 \%$ and $10 \%$ significant levels, respectively.

2) The numbers in the brackets are White-corrected standard errors.

3) Industry and city fixed effects are controlled.

there are more suppliers, by using formal contracts the firm can assure the suppliers that it will not switch, which helps foster specific investments by the suppliers.

\subsection{Robustness checks}

Models 2-7 in Table 3 check other factors that might affect firms' decisions on adopting formal contracts with suppliers. Models 2-7 in Table 3 follow the respective model specifications used in models 2-7 in Table 2. As reported in Table 3, the three variables in the basic model (Eq. (2)) - firm size, the dummy for outside-the-city suppliers, and the number of suppliers - remain statistically significant and positive in all regressions. Hence, the results obtained in Section 5.1 are robust. In addition, models 2,3 and 5 show that neither relationship duration, ownership type, nor outside city competition has significant impact on formal contracts; model 4 suggests that the basic results are unaffected by excluding firms with overseas suppliers; model 6 again tells that there is no significant difference in the contracting behavior between manufacturing and services firms; and model 7 shows that the basic results hold when the ratio of outside-the-city suppliers to total suppliers is used as a substitute for the location dummy, CityDummy, in the regression.

Note that we conduct our analysis on firms' contracting behavior with their clients in Section 4 with one subset of the data (i.e., those firms having contracting information with their clients) and that one contracting behavior with their suppliers in Section 5 with on subset of the data (i.e., those firms having contracting information with their suppliers), separately. We choose this approach for clearer exposition and also because we have a prior that they could be somewhat different. We have also run a regression with all the data (the two subsets, which are not necessarily mutually exclusive, as just mentioned). From this pooled dataset, we find that the main results reported in model 1 of Table 2 and model 1 of Table 3 are not altered qualitatively: the sign and significance of each estimate remain the same.

\section{Concluding remarks}

Why do firms use formal contracts with business partners? This paper uses survey data from a large number of Chinese firms to uncover some important factors about firms' contracting behavior. We find that larger firms are more likely to use formal contracts to govern transactions with their clients and suppliers. We also identify geographical location as an important factor in affecting a firm's contracting decision. We find that a firm is more likely to use formal contracts with their clients and suppliers if the clients and suppliers are located in cities different from the firm's main business location. Firms are more likely to have formal contracts with their clients (suppliers) if the number of clients (suppliers) is smaller (larger). These results are robust when our tests introduce other plausible explanatory variables such as a firm's relationship duration with its clients or suppliers, exports and ownership type. The results hold for both manufacturing and services sectors. 
Our study examines empirically what factors are important for a firm's decision to have formal contracts or relational contracts with its clients and suppliers. Our results imply that formal contracts are not always used and relational contracts may govern many transactions. Even if formal contracts have been signed, the unexplored part of our data also indicates that firms do not always turn to the court when there is a dispute. In future studies, we will investigate factors that prevent firms from going to the court in the presence of disputes.

\section{Acknowledgements}

We thank the referee for his/her very helpful comments and suggestions. We also benefit from comments by Xinyu Hua, Qing Liu, and participants in various seminars and workshops in which earlier versions of this paper (under different titles) were presented. This project is financially supported by the Mrs. Li Ka Shing Fund of the University of Hong Kong.

\section{References}

Asanuma, B. (1989). Manufacturer-supplier relationships in Japan and the concept of relation-specific skill. Journal of Japanese and International Economies, 3(1), $1-30$.

Atiyah, P. S. (1989). An introduction to the law of contract. Oxford: Clarendon Press.

Baker, G., Gibbons, R., \& Murphy, K. (1994). Subjective performance measures in optimal incentive contracts. Quarterly Journal of Economics, 109, 1125-1156.

Baker, G., Gibbons, R., \& Murphy, K. (2002). Relational contracts and the theory of the firm. American Economic Review, 109, $1125-1156$.

Battigalli, P., \& Maggi, G. (2002). Rigidity, discretion, and the costs of writing contracts. American Economic Review, 92(4), $198-817$.

Battigalli, P. and G. Maggi, 2003, “Costly contracting in a long-term relationship", Mimeo, Princeton University

Boerner, C. S., \& Macher, J. T. (2002). Transaction cost economics: An assessment of empirical research in the social sciences Working paper.

Bolton, P., \& Dewatripont, M. (2005). Contract theory. Cambridge, Massachusetts: The MIT Press.

Bull, C. (1987). The existence of self-enforcing implicit contracts. Quarterly Journal of Economics, 102, 147-159.

Corts, K. (2007). The interaction of implicit and explicit contracts in construction and procurement contracting Working Paper.

Klein, B. (1996). Why hold-ups occur: The self-enforcing range of contractual relationships. Economic Inquiry, $34,444-463$.

Levin, J. (2003). Relational incentive contracts. American Economic Review, 93(3), 835-857.

Lyons, B. R. (1996). Empirical relevance of efficient contract theory: Inter-firm contracts. Oxford Review of Economic Policy, 12(4), $27-52$.

Macaulay, S. (1963). Non-contractual relations in business: A preliminary study. American Sociological Review, $28,55-67$.

MacLeod, W. B. (2002). Complexity and contract. In E. Brousseau, \& J. -M. Glachant (Eds.), The Economics of Contracts: Theories and Applications. London: Cambridge University Press.

MacLeod, B., \& Malcomson, J. (1998). Motivation and markets. American Economic Review, 88(3), 388-411.

McMillan, J., \& Woodruff, C. (1999). Dispute prevention without courts in Vietnam. Journal of Law, Economics, E Organization, 15(3), 637-658.

McMillan, J., \& Woodruff, C. (1999). Interfirm relationships and informal credit in Vietnam. Quarterly Journal of Economics, $114,1285-1320$.

Milgrom, P. R., North, D. C., \& Weingast, B. R. (1990). The role of institutions in the revival of trade: The Law Merchant, private judges, and the Champagne Fairs. Economics and Politics, 2(1), 1-23.

Pearce, D., \& Stacchetti, E. (1998). The interaction of implicit and explicit contracts in repeated agency. Games and Economic Behavior, 23(1), 75-96.

Shapiro, C., \& Stiglitz, J. (1984). Equilibrium unemployment as a worker discipline device. American Economic Review, 74(3), 433-444.

Zanarone, G. (2007). Vertical restraints in relational contracts Working Paper. 